\title{
NEDESTRUKTIVNÍ ZKOUŠENÍ STŘíKANÉHO BETONU
}

\author{
NONDESTRUCTIVE TESTING OF SHOTCRETE
}

\author{
Ing. et Ing. Lukáš Kopecký
}

\begin{abstract}
ABSTRAKT
Stříkané betony jsou v současné době používány stále častěji zejména na menších stavbách $\mathrm{v}$ pozemním stavitelství, kde je stř́kaný beton aplikován ručním způsobem nástřiku. Kvalita takových konstrukcí nebývá př́liš často kontrolována a to především díky náročnosti provedení běžně používaných destruktivních zkoušek. Pro popis kvality betonových konstrukcí lze však využít i nedestruktivních zkušebních metod založených na rychlosti průchodu ultrazvukového impulsu konstrukcí. Provedený experiment zaměřený na ověrení vhodnosti jednotlivých metod ultrazvukového prozvučování zkušební desky a jádrových vývrtů z ní vyrobených ukázal, že nejlepší shody výsledků pro popis homogenity dosáhneme při použití metody nepřímého prozvučování zkušební desky a přímého prozvučování jádrových vývrtů. Provedení ověření kvality stř̌íkaného betonu pomocí přímého či polopřímého ultrazvukového prozvučování je však v praxi obtížné a proto předložený článek navrhuje řešení.
\end{abstract}

Klíčová slova: Stríkaný beton, kvalita betonu, pevnost v tlaku, rychlost šîrení ultrazvukového impulzu

\section{ABSTRACT}

Sprayed concrete is recently used mainly for creating small structures in building construction, where sprayed concrete is placed by manual spraying way. Quality of small constructions is not often checked because of difficulties of making ordinarily used destructive tests. For description of concrete construction quality is possible to use nondestructive testing based on velocity of ultrasound impulse through structure. Experiment was based on checking of appropriateness of using ultrasound testing measured on test slab and cores made from test slab. Experiment shows that the best results for describing homogeneity were obtained by semi-direct ultrasonic testing and direct ultrasonic testing on cores. Verification of the shotcrete quality using direct or semi - directultrasonic testing is difficult to do in the reality and therefore this article proposes a solution.

Key words: Shotcrete, concrete quality, compressive strength, velocity of spreading, ultrasound impuls

\section{1 ÚVOD}

S rozvojem použití stř́kaných betonů nejen v podzemním stavitelství ale také v pozemním stavitelství jsou na stř́ḱkané betony kladeny stále výší kvalitativní požadavky. Kvalita betonových konstrukcí je kontrolována zejména u velkých staveb, při použití velkého objemu stříkaného betonu. U menších staveb, kde je prováděn nástřrik stř́kaného betonu manuálně, je kvalita betonu kontrolována zř́́dka a to zejména $\mathrm{v}$ důsledku nákladů na provádění kvalitativních zkoušek. Tyto zkoušky jsou nejčastěji destruktivního charakteru a poškozují konstrukci, z níž jsou odebrány. Stále častěji se začíná využívat nedestruktivního zkoušení betonových konstrukcí, které je pouze doplňováno menším množstvím destruktivních zkoušek. Výsledky nedestruktivních zkoušek nejsou schopny plně nahradit vypovídající hodnotu zkoušek destruktivních, ale umožňují výrazně snížit počet destruktivních zásahů do 
konstrukce. Jejich nenáročné provedení a nízké finanční náklady pak umožňují provedení zkoušek kvality nástřiku i u malých staveb, kde by běžně kvalita nástřiku zkoušena nebyla.

\section{PŘÍPRAVA EXPERIEMNTU}

Důležitým faktorem vypovídajícím o kvalitě betonové konstrukce je především její pevnost a stejnorodost (homogenita). Stejnorodost betonové konstrukce lze hodnotit na základě objemové hmotnosti, pevnosti a rychlosti šírení ultrazvukových vln materiálem. Hodnoty objemové hmotnosti a pevnosti pro hodnocení kvality betonové konstrukce lze stanovit pouze z výsledků provedených destruktivních zkoušek. Popis kvality betonové konstrukce využívající výsledky zkoušky rychlosti průchodu ultrazvukového impulzu je metodou nedestruktivní a proto mu v tomto článku bude věnována největší pozornost.

Rychlost průchodu ultrazvukového impulzu byla stanovena na základě měření doby průchodu ultrazvukových vln vzorkem pomocí přístroje Tico (firmy Proceq) se sondami $82 \mathrm{kHz}$. Pro stanovení rychlosti průchodu ultrazvukového impulzu byly využity metody prrímého a polopřímého prozvučování zkušebního tělesa a metody př́ímého prozvučování jádrových vývrtů zkušebního tělesa.

\subsection{Výroba zkušebních těles}

Pro potřeby experimentu bylo zkušební těleso odebráno na stavbě, kde byl stř́kaný beton aplikován ručním způsobem suchou technologií nástřiku a tvořil krycí vrstvu pilotové stěny. Suchá směs stř́kaného betonu byla vyrobena $\mathrm{v}$ certifikované betonárně a voda byla do směsi přidávána $\mathrm{v}$ průběhu nástřiku operátorem trysky. Složení betonové směsi stř́ikaného betonu popisuje Tab. 1 .

\begin{tabular}{|c|c|c|c|c|}
\hline třída betonu & CEM II 32,5 R & kamenivo 0 - 4 mm & popílek & voda \\
\hline SB 15 (C12/15) & 300 & 1703 & 100 & 150 \\
\hline
\end{tabular}

Tab. 1 Receptura v kg na $1 \mathrm{~m}^{3}$ betonu

Odběr vzorků stříkaného betonu $\mathrm{v}$ in situ byl proveden do formy odpovídající požadavků normy ČSN EN 14488-1 [1] o rozměrech 500x500x150mm. Zkušební těleso bylo ponecháno po dobu 28 dní na stavbě, aby podmínky zrání betonové směsi odpovídaly podmínkám zrání betonu v reálné konstrukci.

Ze zkušební desky bylo odvrtáno 9 vývrtů tvaru válce o průměru $100 \mathrm{~mm}$ a výšky $150 \mathrm{~mm}$ (Obr. 1). Podstavy vývrtů byly mechanicky zarovnány a byla výška upraveného vývrtu100mm. Následně bylo u vývrtů provedeno měřením rychlosti průchodu ultrazvukového impulzu, kdy budič i přijímač byly umístěny v ose jádrového vývrtu (Obr. 5).

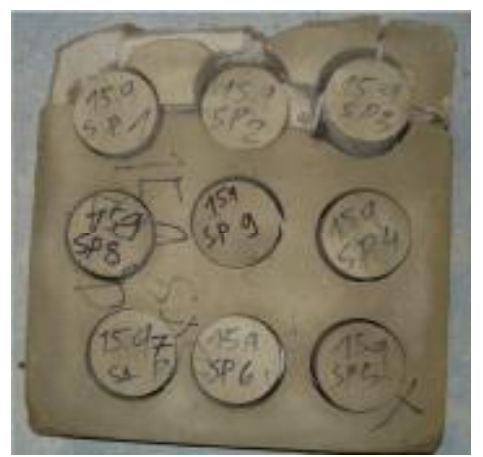

Obr. 1 Rozmístění jádrových vývrtů [4] 


\section{EXPERIMENT}

\subsection{Př́prava měření}

Po 28 dnech zrání bylo zkušební těleso převezeno do laboratoře. Pro měření doby průchodu ultrazvukového impulzu zkušebním tělesem bylo nutné navrhnout rozmístění měřících bodů pro sondy. Měříí body (Obr. 2) byly rozmístěny po obvodu vzorku tak, že první bod byl ve vzdálenosti $50 \mathrm{~mm}$ od kraje desky. Následně byly vyznačeny další body, jejichž osová vzdálenost byla $100 \mathrm{~mm}$. Tímto způsobem byly vyznačeny body v na sobě rovnoběžných stěnách (body 1, 2, 3, 4 a 5) a totožným způsobem byly vyznačeny body na zbývajících dvou stěnách (body 1', 2', 3', 4' a 5'). Po vyznačení bodů byla změřena jejich vzájemná vzdálenost.

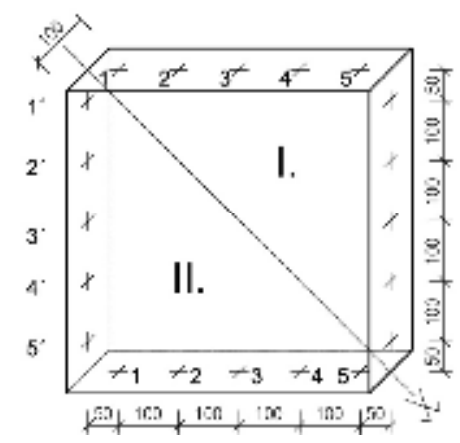

Obr. 2 Rozměření měřících bodů[4]

\subsection{Metoda př́mého prozvučování zkušební desky}

Přri metodě přímého prozvučování byl měřen čas průchodu ultrazvukového impulzu mezi dvěma rovnoběžnými bočními stěnami. Nejprve byl budič a přijímač měřící sondy umístěn do protilehlých bodů - nejprve 1-1, následně 2-2, 3-3, 4-4, 5-5. U každého měření byl čas průchodu ultrazvukového impulzu změřen $3 \mathrm{x}$. Z naměřených hodnot byl stanoven aritmetický průměr. Následně byl budič a přijímač umístěn v kolmém směru na původní měření a byl měřen čas průchodu ultrazvukového impulzu mezi body $1^{\prime}-1^{\prime}, 2-2^{\prime}, 3^{\prime}-3^{\prime}, 4-4^{\prime}$ a $5^{\prime}-5^{\prime}$. Uložení budiče a přijímače je pro jednotlivé experimenty ukázáno na Obr. 3.
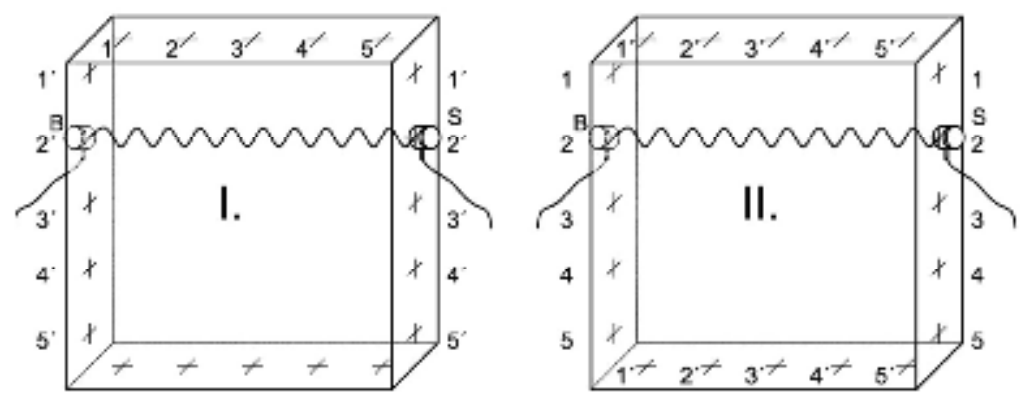

Obr. 3 Schéma přímého prozvučování [4]

\subsection{Metoda polopřímého prozvučování zkušební desky}

Při metodě polopř́mého prozvučování byly rychlosti průchodu ultrazvukového impulsu stanoveny ve dvou oblastech. Dělící osa jednotlivých oblastí byla vedena úhlopř́ičně zkušební deskou. Jednotlivé oblasti jsou znázorněny na Obr. 4. 
Měření bylo nejprve provedeno v oblasti I., kdy byl budič umístěn v bodě 1 a přijímač v bodě $1^{\prime}$. Následně byl přijímač postupně přemístěn do bodu 2', 3', '4,' 5'. Budič byl po provedení první série měření přemístěn do bodu 2 a následně byla provedena opět série měření mezi body 2 a body 1', 2', 3', 4', 5'. Budič byl stejným způsobem postupně přesunut z bodu 1 až do bodu 5 . Celkem bylo provedeno pět sérií po pěti měřeních. Každé měření bylo provedeno $3 \mathrm{x}$ a byl stanoven průměr každého měření. Shodným způsobem bylo provedeno měření v oblasti II.
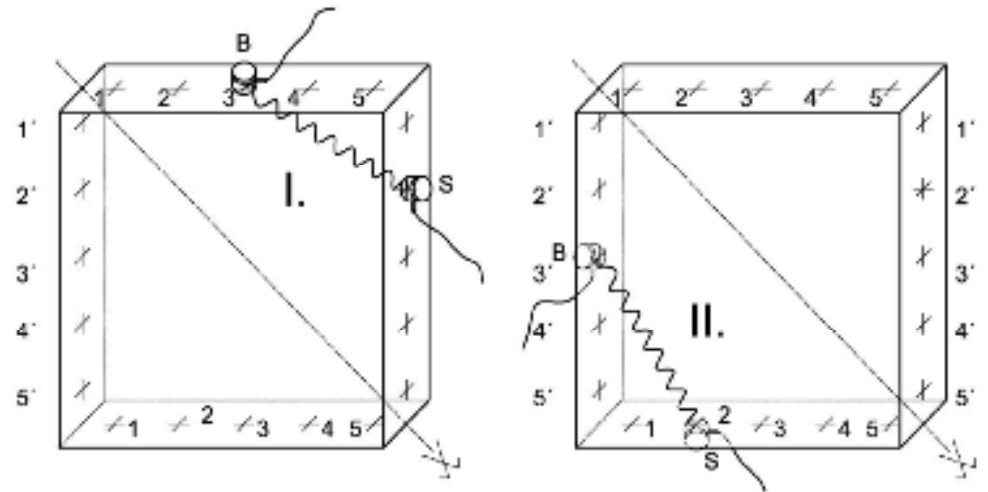

Obr. 4 Schéma polopřímého prozvučování [4]

\subsubsection{Metoda přímého prozvučování jádrových vývrtů}

Pro doplnění informace o ověření vhodnosti metod přímého a polopřímého prozvučování byl experiment doplněn o měření doby průchodu ultrazvukového impulsu jádrovými vývrty. Na jádrových vývrtech tvaru válce byl budič a přijímač umístěn vždy v ose jádrového vývrtu Obr. 5.

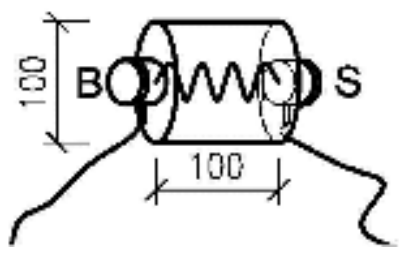

Obr. 5 Schéma přímého prozvučování jádrových vývrtů (B-budič, S-snímač)

\subsubsection{Zkouška pevnosti v dostředném tlaku}

Jako doplňková zkouška ke zkoušce rychlosti šîrení ultrazvukového impulzu na jádrových vývrtech byla zvolena zkouška pevnosti v dostředném tlaku dle normy ČSN EN 12390-3[2]. Účelem zkoušky bylo porovnat spojitost hodnot rychlosti šíření ultrazvukového impulzu s hodnotami pevnosti betonu v tlaku na jádrových vývrtech. Pevnost byla zkoušena na hydraulickém lise EDT 1600, s rychlostí zatěžování $0,6 \mathrm{MPa} / \mathrm{s} \pm 0,2 \mathrm{MPa} / \mathrm{s}$.

\section{VYHODNOCENÍ EXPERIMENTU}

\subsection{Porovnání rychlosti šírení ultrazvuku}

Ze změřených časů průchodu ultrazvukového impulzu zkušebními tělesy po známé dráze (vzdálenost budiče a přijímače) byla stanovena rychlost šíření ultrazvukového impulzu. Rychlost šíření 
ultrazvukového impulzu byla vypočtena z naměřených hodnot dle normového vztahu dle ČSN 7313 $71[3]:$

$$
v_{u z}=\frac{L}{T}\left[m \cdot s^{-1}\right]
$$

L - vzdálenost mezi budičem a přijímačem [mm]

$\mathrm{T}$ - čas, který uplyne při průběhu impulsu měřící základnou $[\mu \mathrm{s}]$

Vypočítané rychlosti byly znázorněny pomocí povrchových grafů, kde jsou pomocí izolinií viditelná jednotlivá pásma se stejnotou rychlostí průchodu ultrazvukových vln

\subsubsection{Př́mé prozvučování zkušební desky}

Z vypočtených průměrných výsledků rychlosti šíření ultrazvukového impulzu metodou přímého prozvučování je zřejmé, že zkušební deska je stejnorodá ve všech částech. Ve střední části byla rychlost ultrazvuku v jednom z měřených směrů vyšší, což se ale neprojevilo při měření provedeném ve směru kolmém na směr prvního měření. Lze tedy konstatovat, že na základě metody přímého prozvučování se deska jeví jako stejnorodá.
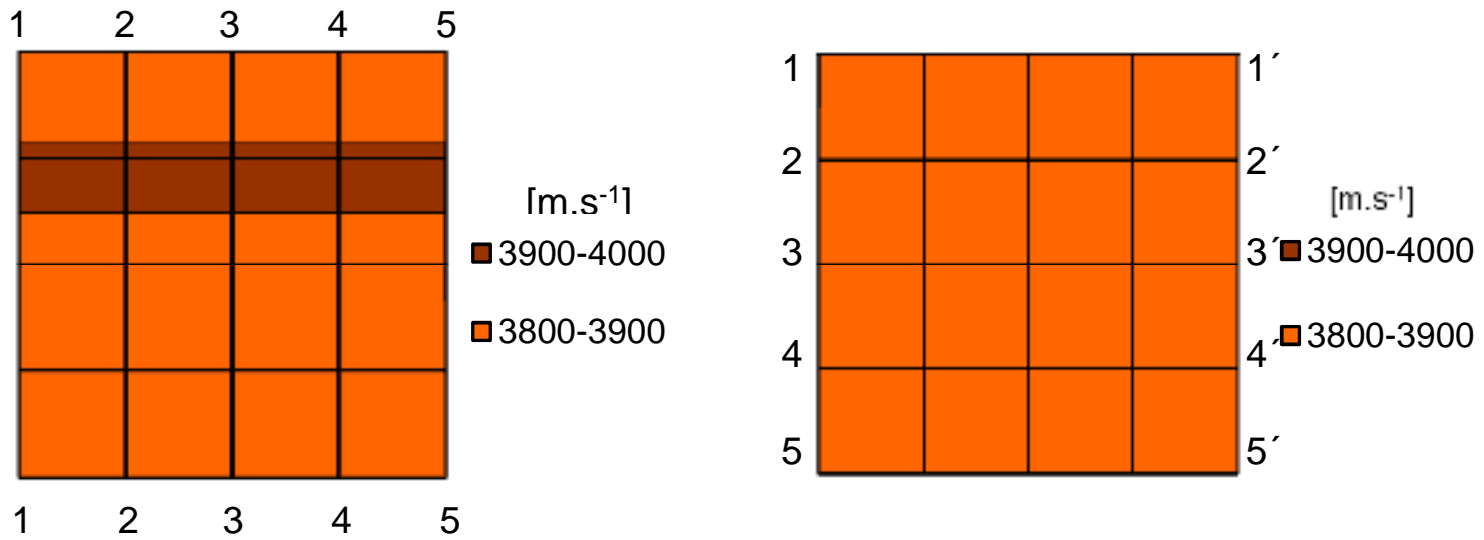

Obr. 6 Př́mé prozvučování zkušební desky[4]

\subsubsection{Poloprímé prozvučování zkušební desky}

Z průměrných rychlostí šíření ultrazvuku zjištěných metodou polopřímého prozvučování je naopak zřejmá různorodost zkušební desky. Při porovnání grafư v obrázku 6 je zřejmé, že oba grafy jsou téměř totožné, pouze osově obrácené. Nepřímá metoda měření nám poskytuje přesnější popis zkušební desky, což je také dáno tím, že je v diagonálním směru provedeno více měření (více kombinací bodů jednotlivých měřících bodů. 

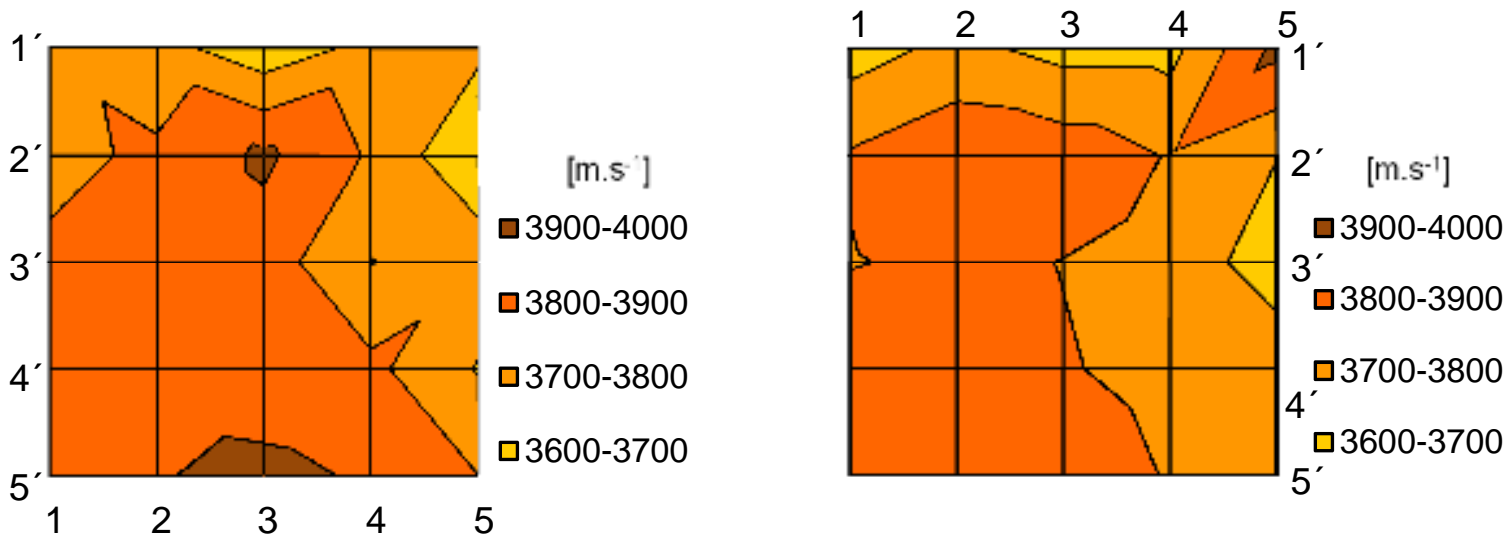

Obr. 7 Polopřímé prozvučování zkušební desky[4]

\subsubsection{Př́mé prozvučování a stanovení pevnosti v tlaku jádrových vývrtů}

Stanovené rychlosti šiření ultrazvukového impulzu jednotlivými jádrovými vývrty jsou znázorněny v prostorovém grafu na Obr. V. Při porovnání grafů na Obr. 7 a 8 se lze domnívat, že metoda přímého prozvučování jádrových vývrtů a metoda polopřímého prozvučování celé zkušební desky vykazuje obdobné výsledky.

Při porovnání jádrových vývrtů, u kterých byla vypočtena vyšší rychlost šíření ultrazvuku s vývrty, u kterých byla vypočtena vyšší pevnost v tlaku, dojdeme k závěru, že rozložení vyšších rychlostí šíření ultrazvuku nekoreluje s rozložením vyšších pevností betonu v tlaku. Lze tedy konstatovat, že u provedených měření nebyla nalezena souvislost mezi rychlostí šíření ultrazvukového impulzu a pevností v tlaku.
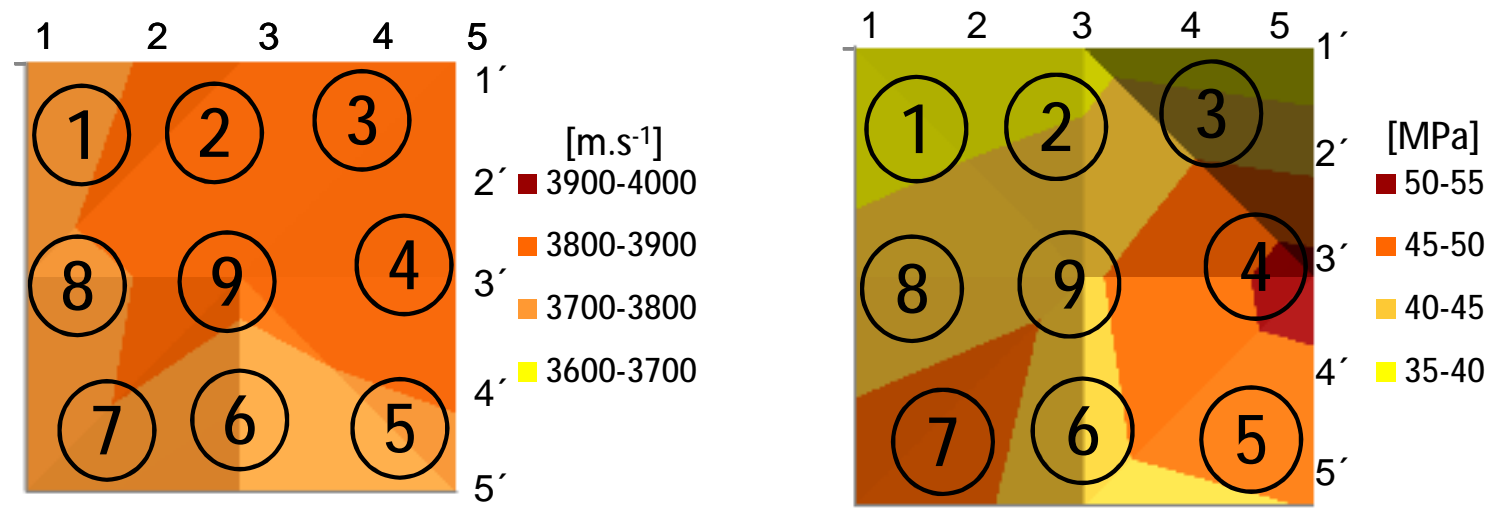

Obr. 8 Rychlost šîrení ultrazvuku při přímém prozvučování a pevnost v tlaku na jádrových vývrtech[4]

\section{ZÁVĚR:}

Z výsledků experimentu lze usuzovat, že pravděpodobně nejvhodnější metodou pro stanovení homogenity betonových konstrukcí pomocí rychlosti šíření ultrazvukového impulzu zkušebním tělesem je metoda polopř́mého prozvučování. Toto konstatování potvrzují i výsledky zkoušek provedených na jádrových vývrtech, které téměř přesně korelují s hodnotami naměřenými u deskového zkušebního tělesa. Na reálné konstrukci je však provedení metody měření polopřímým 
prozvučováním značně obtížné, nebot' je většinou konstrukce přístupná pouze z jedné strany. Provedení jádrových vývrtů je zase poměrně nákladné a dochází při něm k poškození konstrukce. Jako vhodná alternativa měření se nabízí metoda měření rychlosti ultrazvuku, při které je snímač a budič přikládány podle zvoleného rastru na př́stupný povrch konstrukce. Tato metoda však vyžaduje velké množství měření. Jako vhodné se pak jeví využití přístrojů, které umožňují nepřímé prozvučování přiložením soustavy sond na povrch konstrukce. Tyto sondy umožňují měření i při prrístupu konstrukce pouze z jedné strany, kdy dochází ke zpětnému odražení ultrazvukového vlnění od vnitřního líce konstrukce zpět do přijímače. Příkladem takového př́istroje může být výrobek od firmy Proceq Pundit PL-200PE se sondou $50 \mathrm{~Hz}$ a pulzním převodníkem, který umožňuje zjištování tloušt'ky konstrukce, detekci a lokalizaci vad a plošné skenování konstrukce v reálném čase.

Z výsledků provedených experimentů rovněž vyplývá, že není možné prokázat přímou závislost rychlosti šîrení ultrazvuku a pevností v tlaku. Pro ověření možné závislosti by však bylo potřeba provést měření na více zkušebních tělesech.

\section{Použitá literatura}

[1] ČSN EN 14488-1Zrušení stř́kaného betonu - Část 1: Odběr vzorku čerstvého a ztvrdlého betonu, ČNI 2006

[2] ČSN EN 12390-3 Zkoušení ztvrdlého betonu - Část 3: Pevnost v tlaku zkušebních těles, ÚNMZ, Praha 2009

[3] ČSN 731371 Nedestruktivní zkoušení betonu - Ultrazvuková impulzová metoda zkoušení betonu, ÚNMZ, Praha 2011

[4] KOPECKÝ, Lukáš. Hodnocení kvality provedení ručně stř̌́kaného betonu. Brno, 2016. Disertační práce. Vysoké učení technické v Brně, Fakulta stavební. Vedoucí práce Doc. Ing. Karel Dočkal,.CSc. 